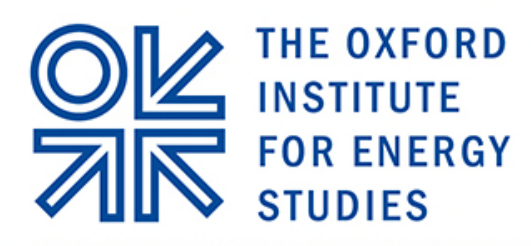

A RECOGNIZED INDEPENDENT CENTRE OF THE UNIVERSITY OF OXFORD

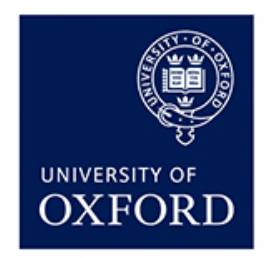

July 2016

\title{
Azerbaijan's gas supply squeeze and the consequences for the Southern Corridor
}

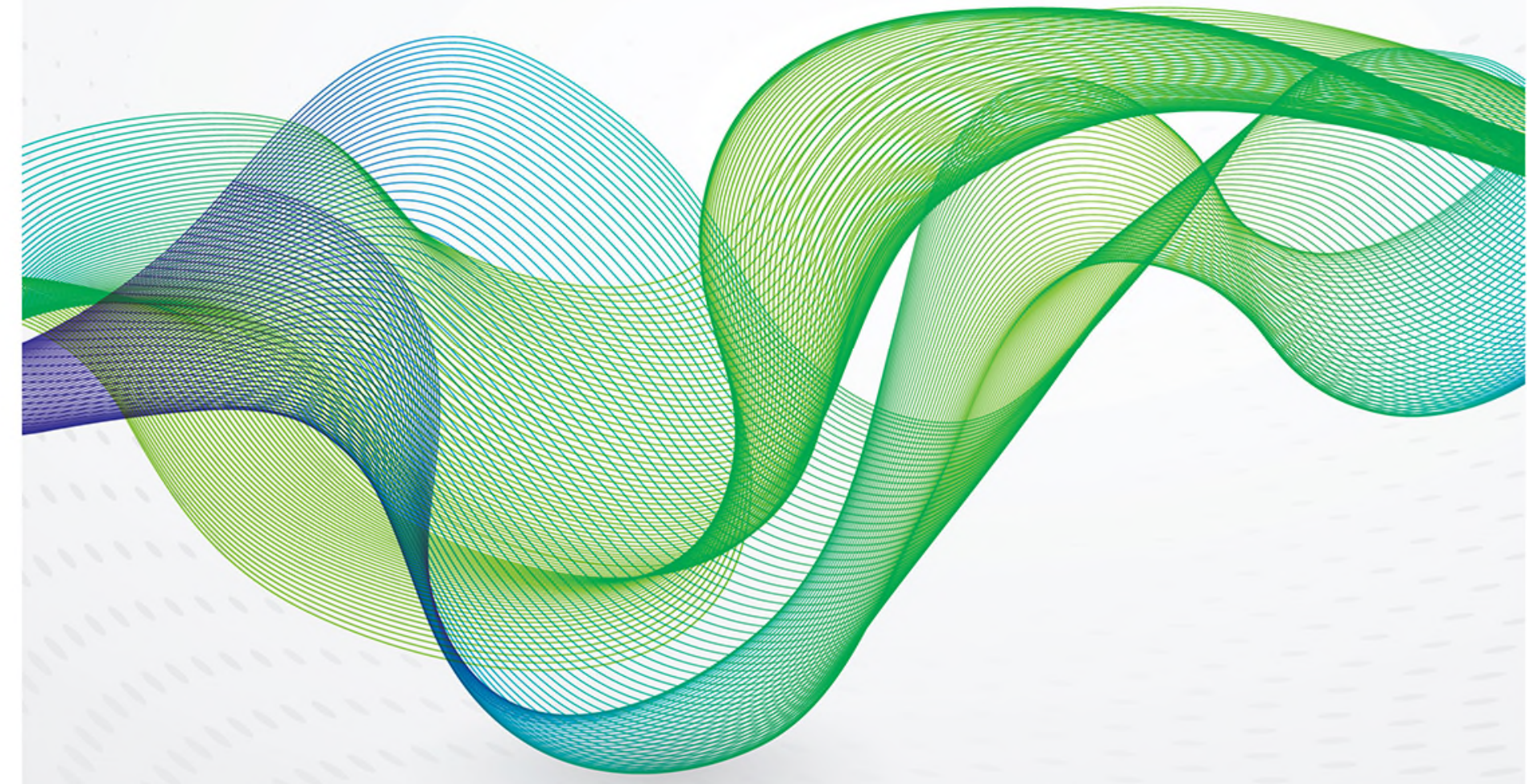



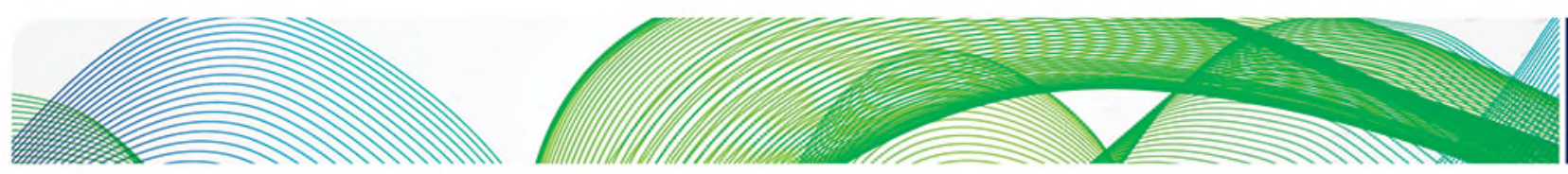

\section{애잔}

The contents of this paper are the author's sole responsibility. They do not necessarily represent the views of the Oxford Institute for Energy Studies or any of its members.

Copyright @ 2016

Oxford Institute for Energy Studies

(Registered Charity, No. 286084)

This publication may be reproduced in part for educational or non-profit purposes without special permission from the copyright holder, provided acknowledgment of the source is made. No use of this publication may be made for resale or for any other commercial purpose whatsoever without prior permission in writing from the Oxford Institute for Energy Studies.

ISBN 978-1-78467-062-7 

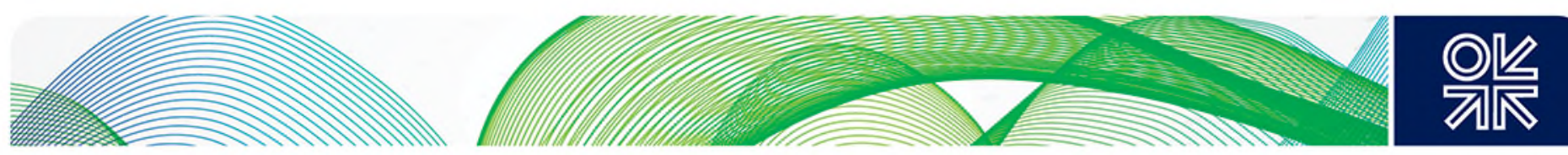

\section{Preface}

In the post-Soviet era of the early 1990s, Azerbaijan attracted major upstream companies to participate in the development of existing fields and in the exploration for new oil and gas discoveries. The implementation of the Azeri-Chirag-Gunashli and Shah Deniz projects can be regarded as successful outcomes of this process. In the 2000s Europe, from a policy perspective, intensified its search for alternatives to Russian pipeline gas imports. The 'Southern Corridor' was viewed by many as the key element in this strategy for gas supply diversification. Whilst Shah Deniz 2 gas will flow beyond Turkey to South East Europe and Italy, volumes are modest compared with the original Southern Corridor 'vision'. The reality of a lack of firm supply available to 2030 for this route has been addressed in previous OIES papers.

This paper by Simon Pirani follows from his previous published work on Caspian and Central Asian markets and supply. Whilst most observers and analysts have focussed on the uncertainty of the scale and timing of production from future field developments, this paper addresses the more immediate problem of the unforeseen decline in the legacy state-operated fields. In any producing province, predicting the decline rate in post-plateau field production is prone to error. In the case of Azerbaijan the reduction in funds available for sustaining investment and the damage inflicted on the shallow water portion of the Gunashli field have exacerbated this issue.

The paper follows from previous OIES Gas Programme publications on European supply and is especially relevant as part of any assessment of Europe's supply situation in the 2020s in a post LNG supply surplus era.

\section{Howard Rogers}

Oxford

July 2016 

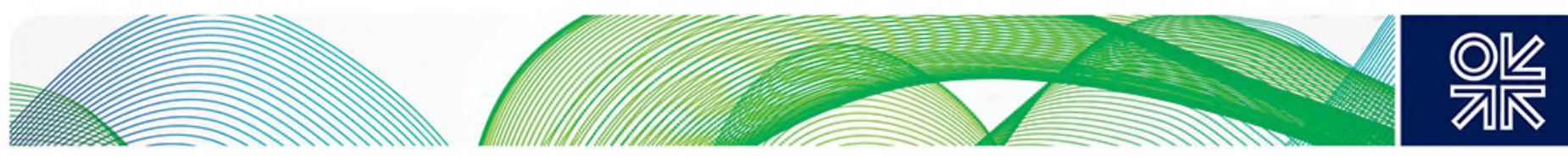

\section{About the Author}

Simon Pirani is a Senior Research Fellow on the Natural Gas Research Programme at the Oxford Institute for Energy Studies, and co-editor of The Russian Gas Matrix: How Markets are Driving Change (Oxford University Press, 2014). He is author of numerous books and papers on natural gas issues in former Soviet countries, including Central Asian and Caspian Gas Production and the Constraints on Export (OIES, 2012). Before joining the Institute in 2007, Dr Pirani wrote about energy and the economy of former Soviet countries as a journalist and historian. 

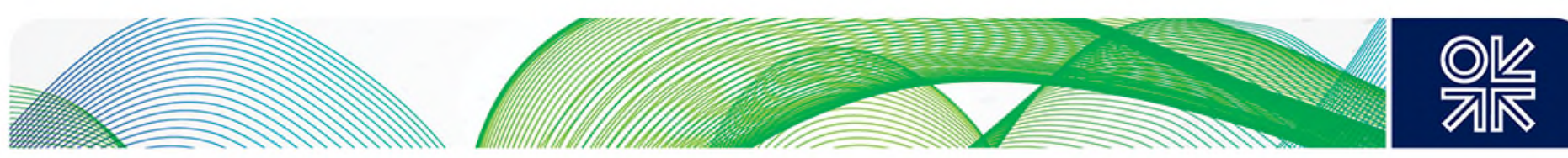

\section{Contents}

Preface

ii

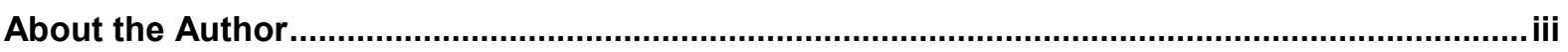

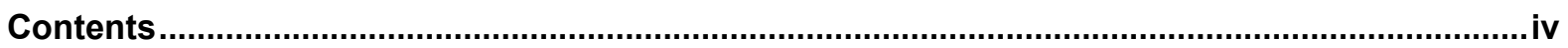

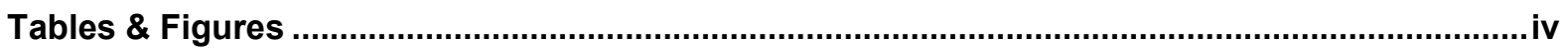

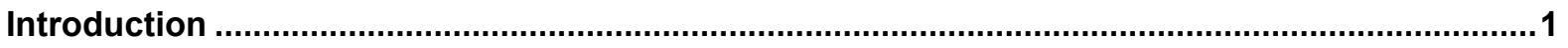

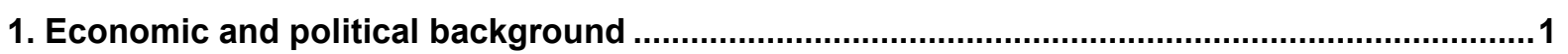

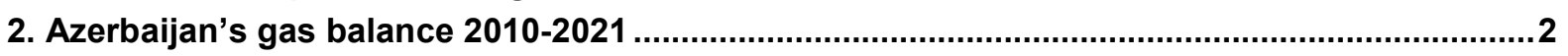

3. Problematic production estimates ......................................................................................8

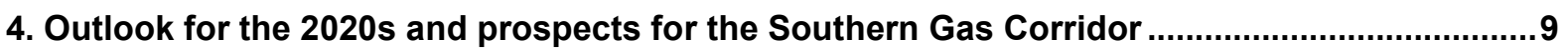

5. Implications for the Southern Corridor and conclusions .................................................12

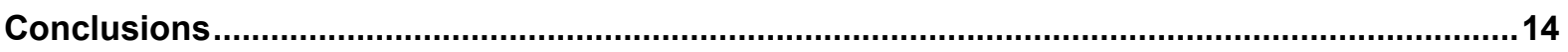

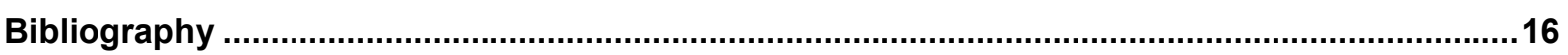

\section{Tables \& Figures}

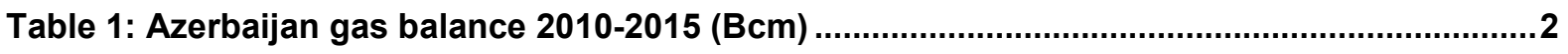

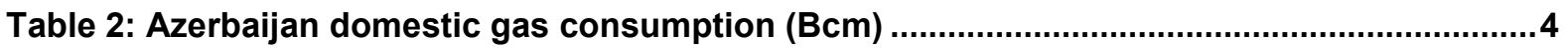

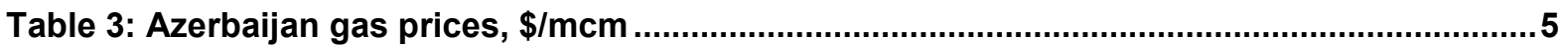

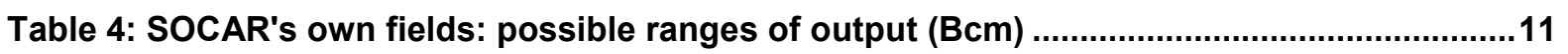

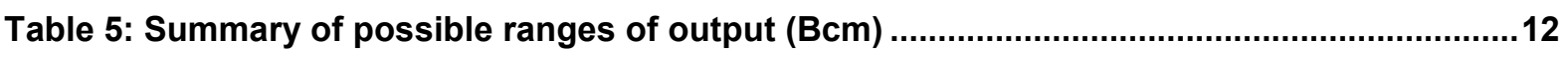

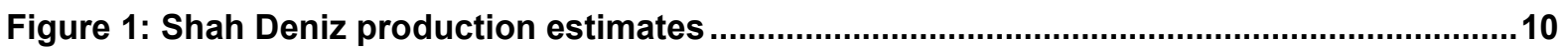



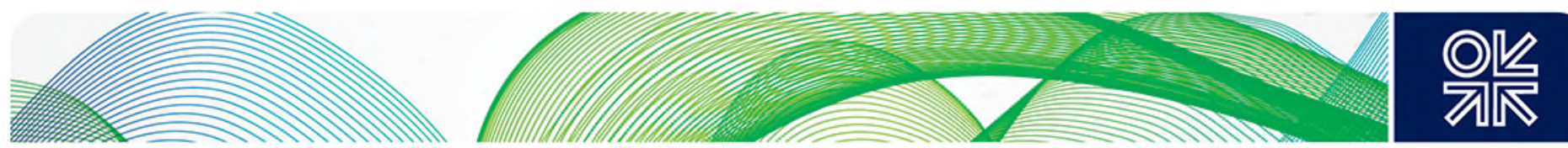

\section{Introduction}

The purpose of this paper ${ }^{1}$ is to take a fresh look at Azerbaijan's gas balance, in the light of recent indications that Azerbaijan, which became a gas exporter in 2007, has found itself short of gas. Small volume exports to southern Russia that started in 2010 were halted in 2014. Georgia, for which Azerbaijan had become the main supplier in 2006, imported extra volumes from Russia in 2014. In 2015 a large private consumer in Azerbaijan itself contracted to buy Russian volumes, but the deal was aborted. Then in 2016 SOCAR, Azerbaijan's state oil and gas company - which had begun importing fuel oil from Russia and Kazakhstan for power stations that had switched from gas entered negotiations with Russia about importing gas.

The paper examines the extent of Azerbaijan's supply squeeze and considers how soon it may be overcome - issues that relate to Azerbaijan's potential as a future supplier of gas to the European market and the consequences for the Southern Gas Corridor. The first section sketches the economic and political background; the second looks at the gas balance and why supply has struggled to keep up with demand. The third section considers previous estimates of future gas output growth that now look too optimistic; the fourth assesses prospects in the 2020s. The final section comments on the implications for the southern gas corridor to Europe.

\section{Economic and political background}

Azerbaijan, whose economy is heavily dependent on oil and gas exports, has been particularly seriously affected by the fall in oil prices in 2014-15. The Azerbaijan currency, the manat was devalued by $30 \%$ in February 2015 and by a further 50\% in December 2015 . Azerbaijan's trade surplus has been reduced almost to zero, and its (albeit underdeveloped) banking sector weakened. In 2016 Azerbaijan entered economic recession for the first time in 20 years. In the first four months of 2016, GDP fell $4.5 \%$ year on year and non-oil GDP fell $6.8 \%$ year on year. A construction boom fuelled by high oil prices has ended suddenly; in the first four months of 2016, construction activity was $35.5 \%$ lower year-on-year. ${ }^{2}$ The return of economic recession has been accompanied by the resurgence in April 2016 of the "frozen" military conflict with Armenia over Nagorno-Karabakh, the territory in western Azerbaijan that has been under Armenian military control since the war between the two states in 1992.

Falling oil prices have aggravated and highlighted long-term economic problems that were emerging due to the decline in oil production, from 2010 , and the lack of diversification away from dependence on it. The IMF issued a marked warning in 2013 that, given the possible depletion of oil reserves within 15-20 years, and the fact that increased gas production would be unlikely to help offset the oil revenue decline, "oil dependence and fiscal vulnerabilities [were] rapidly increasing", as reflected in too strong a link between spending and current oil prices. The IMF specifically warned of the fiscal risks inherent in the aggressive investment plan, both domestically and abroad, by SOCAR, the

\footnotetext{
${ }^{1}$ The author would like to acknowledge the help of colleagues at OIES, in particular James Henderson, Howard Rogers, Gulmira Rzayeva and Jonathan Stern, and that of contacts and colleagues in industry, in Azerbaijan and other countries.

${ }^{2}$ AzStat (the State Statistical Committee of Azerbaijan, http://www.stat.gov.az/indexen.php); Galt \& Taggart, Azerbaijan Weekly Market Watch, various issues; Fitch Ratings, Azerbaijan: full rating report (3 March 2016); Fitch Ratings, "Azerbaijan's Banking Sector Post Devaluation" (April 2016)
} 

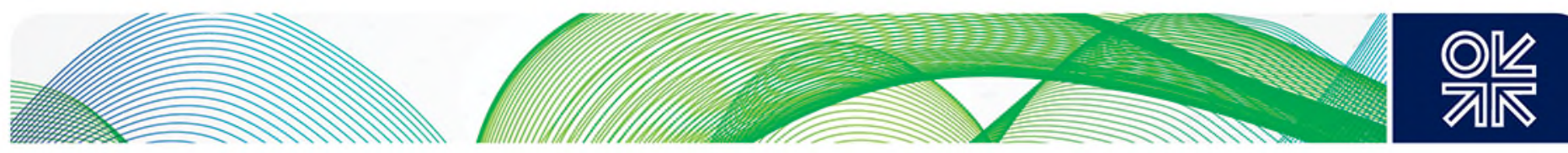

national oil company. ${ }^{3}$ The fall in oil prices has forced SOCAR, along with most other oil producers, to scale back its investment plans, and this is an element of the problems with gas production.

\section{Azerbaijan's gas balance $\mathbf{2 0 1 0 - 2 0 2 1}$}

Azerbaijan has three main sources of gas: (i) the Shah Deniz field, the country's largest gas resource, where a consortium headed by BP began production in 2007 (current output about 10 bcm/year); (ii) associated gas from the Azeri-Chirag-Guneshli oil field, which is provided free to SOCAR under the PSA between the government and an international consortium headed by BP (about 3 bcm/year); and (iii) volumes produced by SOCAR from the Shallow Water Guneshli field and other smaller fields (about $6 \mathrm{bcm} /$ year). The largest consumer of Azerbaijani gas is the domestic market (about 10 bcm/year in recent years). Since the start-up of Shah Deniz production in 2007, Azerbaijan has exported gas to Turkey (under a contract providing for $6.6 \mathrm{bcm} / \mathrm{y}$ of sales), Georgia (1-2 bcm/y), and southern Russia. There will be a major expansion of gas production from 2018, when the second phase of the Shah Deniz project will be commissioned. When it reaches plateau production in the early 2020s, Shah Deniz II will produce about 16.3 bcm/year of gas. Sales contracts are in place for this gas - $6 \mathrm{bcm} / \mathrm{y}$ to Turkey and $10 \mathrm{bcm} / \mathrm{y}$ to European buyers - and infrastructure under construction (the South Caucasus pipeline expansion (SCPx), the Trans Anatolian pipeline (TANAP) and the Trans Adriatic pipeline (TAP)) to bring it to market. ${ }^{4}$

Table 1 shows the main items in Azerbaijan's gas balance for 2010-2015. It has been assembled mainly from official statistics and publicly available company information.

Table 1: Azerbaijan gas balance 2010-2015 (Bcm)

\begin{tabular}{|c|c|c|c|c|c|c|}
\hline Gas balance & 2010 & 2011 & 2012 & 2013 & 2014 & 2015 \\
\hline Production (commodity gas) & 16.7 & 16.4 & 17.2 & 17.9 & 18.8 & 18.9 \\
\hline ACG associated gas & 3.4 & 3.3 & 3.0 & 2.2 & 2.8 & 3.2 \\
\hline Shah Deniz production & 6.9 & 6.7 & 7.5 & 9.8 & 9.9 & 9.9 \\
\hline SOCAR fields (estimate (residual)) & 6.4 & 6.4 & 6.7 & 5.9 & 6.2 & 5.8 \\
\hline Stock changes & -1.1 & 0.4 & -0.3 & -0.2 & 0.3 & $0.4 \mathrm{e}$ \\
\hline Commodity gas available for market & 15.6 & 16.7 & 16.9 & 17.7 & 19.1 & 19.3 \\
\hline Export & 6.2 & 6.8 & 6.6 & 7.3 & 8.1 & $8.3 \mathrm{e}$ \\
\hline to Russia & 0.8 & 1.5 & $2.0 \mathrm{e}$ & 1.4 & 0.2 & 0 \\
\hline to Turkey & 4.5 & 3.8 & 3.3 & 4.2 & 6.1 & $6.2 \mathrm{e}$ \\
\hline to Georgia & 0.9 & 1.5 & 1.3 & 1.7 & 1.9 & 2.2 \\
\hline Azerbaijan domestic consumption & 9.4 & 9.9 & 10.3 & 10.4 & 11.0 & $10.9 \mathrm{e}$ \\
\hline
\end{tabular}

Sources: AzStat, EMRA (Turkey), news reports. Author's estimates are marked "e"

\footnotetext{
${ }^{3}$ IMF (2013), Republic of Azerbaijan: Selected Issues (country report 13/165) (June 2013), pp. 3-5

${ }^{4}$ There is further background in previous OIES publications on Azerbaijan, and specifically, Julian Bowden, "Azerbaijan: from gas importer to exporter" in S. Pirani (2012), and Rzayeva (2015).
} 

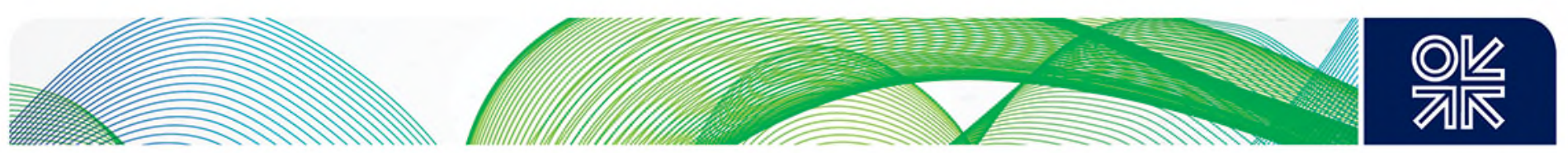

Table 1 shows that Azerbaijan's gas supply squeeze results from trends that have increased demand more rapidly than supply, and some unexpected supply-side factors that have sharpened this disbalance.

\section{Demand-side factors}

The demand for Azerbaijani gas has risen gradually over the last five years in Turkey, Georgia and the domestic market. The accumulated effect is significant: aggregate Azerbaijani gas supply to these three markets rose from $14.8 \mathrm{bcm}$ in 2010 to $19.3 \mathrm{bcm}$ in 2015.

Overall consumption of gas in Turkey, in sharp contrast to the European market, has been growing in the first half of the 2010s and may continue to grow for the rest of the decade. For Turkey, Azerbaijani imports are a means of reducing dependence on Russia, its main supplier. Turkey contracted to purchase $6.6 \mathrm{bcm} /$ year of Shah Deniz gas from 2007, but for several years afterwards was unable to off-take the full amount, mainly due to infrastructure constraints in the east of the country (lack of compressor stations for transport of gas to areas of consumption). These issues were largely resolved in 2013, and in 2014-15 Turkey's import of Azerbaijani gas rose above $6 \mathrm{bcm} / \mathrm{year}$, i.e. came close to the annual contract quantity, for the first time. Spare volumes (i.e. the difference between Turkey's actual offtake and the contract quantity), that had previously been consumed in the Azerbaijani domestic market, were thus no longer available. ${ }^{5}$

Georgia's total consumption of gas rose from 0.9-1.8 bcm/year in the 2000s to 1.1-2.1 bcm/year in the early 2010s, and reached 2.42 bcm in both 2015 and 2016. This substantial increase appears to be driven, firstly, by an intensive gasification programme, and, secondly, by higher consumption in the power sector. The completion in July 2015 of the Gardabani power station, Georgia's first combined cycle gas turbine (CCGT) station, will continue the trend. ${ }^{6}$

Until 2006, Russia was Georgia's sole supplier. In that year, Shah Deniz gas became available, and Georgia reduced its purchases from Russia to $0.2 \mathrm{bcm} /$ year, most of which (around $0.18 \mathrm{bcm}$ in most years) is supplied in lieu of transit fees for transporting Russian gas to Armenia. Against a background of heightened political tension between Russia and Georgia, including the military conflict of 2008, the resumption of higher-volume imports from Russia has in recent years seemed unlikely - but in 2014 Georgian imports from Russia rose to $0.3 \mathrm{bcm}$, and in September-December 2015 a series of meetings were held between Gazprom and Georgian energy ministry officials, reportedly to discuss a further increase. Kakha Kaladze, the Georgian energy minister, made statements in JanuaryFebruary 2016 about the possible resumption of imports from Russia on a larger scale. In March 2016, however, Georgia appeared to opt instead for an agreement to buy more Azerbaijani gas. The intergovernmental agreement between the two countries setting out the terms of gas imports was amended; Kaladze stated that volumes are to be increased from around $1.5 \mathrm{bcm} /$ year to $2 \mathrm{bcm} / \mathrm{year}$, and prices have been reduced, from a reported $\$ 180 / \mathrm{mcm}$ in 2015 , by about $\$ 35-40 / \mathrm{mcm}^{7}$

It appears that one of Georgia's aims was to renegotiate the purchase price of Azerbaijani gas imports. But press reports also indicate that volume was an issue: during the talks with Russia, Georgian officials repeatedly stated that no more gas was available from Azerbaijan. Moreover, press reports indicated that Azerbaijan struggled during the 2015/2016 winter to deliver volumes as required. According to one report, the March agreement amended provisions under which $60 \%$ of gas

\footnotetext{
${ }^{5}$ See Rzayeva, (2015)

${ }^{6}$ Background, Pirani (2012), p. 94. Gas balances, "Ministr energetiki Gruzii o neobkhodimosti priobreteniia rossiiskogo gaza", Sputnik Georgia, 21 October 2015 and "Georgia to increase natural gas imports", Natural Gas Europe, 25 December 2015. Consumption growth, industry sources and "Azerbaidzhan poka ne mozhet polnost'iu pokryt' potrebnosti Gruzii v gaze", Sputnik Georgia 13 January 2016. On Gardabani, “Pervaia TES kombinirovannogo tsikla otkrylos' v Gruzii”, Sputnik Georgia 22 July 2015.

7 "Azerbaidzhan uvelichit postavki gaza v Gruziiu”, RIA Novosti, 4 March 2016; "Azerbaidzhan uvelichit postavki gaza v Gruziiu i snizit tseny", Gruziia On Line, 4 March 2016.
} 

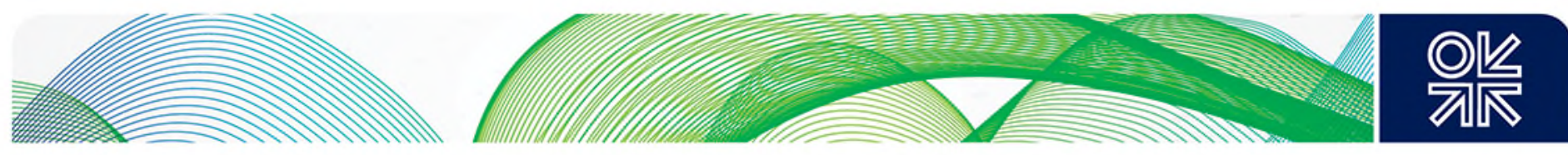

deliveries from Azerbaijan to Georgia are made in winter, and $40 \%$ in summer, to a $70 \%-30 \%$ split, implying a contractual commitment on SOCAR to deliver $450 \mathrm{mcm} /$ day in winter, instead of 385 $\mathrm{mcm} / \mathrm{day}^{8}$

Azerbaijan's domestic market has been the main source of higher demand for Azerbaijani gas in recent years. Table 2 shows how consumption has risen by more than $1.5 \mathrm{bcm}$ in the first half of this decade.

Table 2: Azerbaijan domestic gas consumption (Bcm)

\begin{tabular}{|l|r|r|r|r|r|r|}
\hline & 2010 & 2011 & 2012 & 2013 & 2014 & 2015 \\
\hline \hline Total supply to domestic users & $\mathbf{9 . 3 6}$ & $\mathbf{9 . 9 1}$ & $\mathbf{1 0 . 3 3}$ & $\mathbf{1 0 . 3 7}$ & $\mathbf{1 1 . 0 3}$ & $\mathbf{1 0 . 9 ~ \#}$ \\
\hline Transformation (power, CHP, heat) & 4.24 & 4.76 & 5.36 & 5.45 & 5.68 & $\mathrm{n} / \mathrm{a}$ \\
\hline Energy industries own use & 0.33 & 0.41 & 0.44 & 0.45 & 0.47 & $\mathrm{n} / \mathrm{a}$ \\
\hline Losses & 1.12 & 0.89 & 0.89 & 0.89 & 0.94 & $\mathrm{n} / \mathrm{a}$ \\
\hline Final consumption (industry and constr'n) & 0.61 & 0.74 & 0.98 & 0.99 & 1.06 & $\mathrm{n} / \mathrm{a}$ \\
\hline Final consumption (residential \& comm'cl) & 3.00 & 3.06 & 2.59 & 2.53 & 2.82 & $\mathrm{n} / \mathrm{a}$ \\
\hline Non-energy use & 0.04 & 0.03 & 0.04 & 0.03 & 0.03 & $\mathrm{n} / \mathrm{a}$ \\
\hline \hline
\end{tabular}

Source: AzStat; \# 2015 - OIES estimate

It is striking that most of the increase in gas consumption is accounted for by the power and heat ("transformation") sector, where it rose from $4.24 \mathrm{bcm}$ to $5.68 \mathrm{bcm}$ between 2010 and 2014 (34\% in four years). Electricity consumption also rose considerably, from 18.7 bn kWh to 24.7 bn kWh between 2010 and 2014 (32\%). (It previously hit a peak of 24.5 bn kWh in 2006, falling thereafter due to the financial crisis.) While Azerenergy, the main power generator, states that there have been some efficiency improvements, a key factor in rising gas demand has been the substitution of fuel oil (which made up about one quarter of the fuel mix until 2006, and by 2013 had been eliminated) by gas. New gas-fired stations have added substantially to generating capacity. ${ }^{9}$

Azerenergy, a state-controlled corporation, has been used as an instrument of state-directed policy to support industry and agriculture with subsidised electricity. Some market-reform-oriented measures were taken in 2007, when electricity tariffs more than doubled and a metering system was introduced. But progress was slow, and in 2015, when the manat was devalued, Azerenergy was sharply exposed, having borrowed heavily in dollars to finance investment and being dependent on manat revenues. It accumulated substantial debts both to the budget (these stood at just under 800 million manat at the end of 2015), and to SOCAR, its main gas supplier, which won a court ruling in July 2015 for the payment of (unspecified) debts for gas delivered. ${ }^{10}$ A presidential decree of February 2015 provided for electricity distribution networks to be separated-out into Azerishyg, another stateowned company, ${ }^{11}$ but a more comprehensive reform is awaited.

The second largest source of gas demand is final consumption by households and commercial consumers. The third largest is losses, which at little short of $1 \mathrm{bcm} / y e a r$ (nearly one tenth of the gas

\footnotetext{
8 “Azerbaidzhan poka ne mozhet polnost'iu pokryt' potrebnosti Gruzii v gaze”, Sputnik Georgia, 13 January 2016;

"Azerbaidzhan, Gruziia, Rossiia: tri tochki zreniia na postavki gaza”, Sputnik Georgia, 15 January 2016; John Roberts, "From feast to famine in Azerbaijan", Natural Gas Europe, 24 February 2016

${ }^{9}$ AzStat; Azerenergy corporate presentation, 2012; Hajar Huseynova, Alternative and Renewable Energy Outlook for Azerbaijan 2014, Baku: Konrad Adenauer Stiftung, 2014)

10 "Azerenerji is most exposed corporate to manat devaluation", Fitch Ratings press release, 2 March 2015; "SOCAR wins court case against Azerenergy", APA Azeri Press Agency, 1 July 2015; "Azerenergy owes AZN 780 mln to state budget”, Caspian Energy, 23 May 2016;

11 "Chto tvoritsia vokrug Azerenerdzhi?", Haqqin.az news service, 12 June 2015
} 

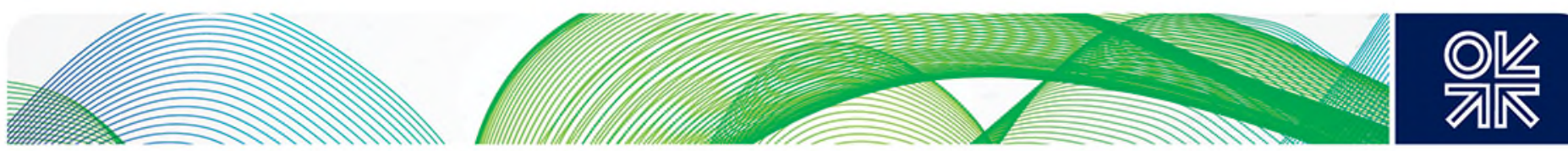

balance) reflect a major potential for improvement. (Note that in Azerbaijan's statistics the row "losses" does not include the energy industry's own use, which is a separate row, and neither does it include the reinjection of gas into hydrocarbons reservoirs or flared gas, both of which are deducted from the gas balance at an earlier stage.)

\section{Gas price issues}

The deterioration of the economic situation in Azerbaijan, and the devaluations in 2015, highlighted the problem of gas prices, as well as electricity prices. Table 3 shows estimates of prices in dollars; the regulated prices in the domestic market fell sharply in dollar terms in 2015, widening an already considerable gap between those prices and well-head prices paid to a private producer, Bahar Energy, on one hand, and export prices paid on the other hand.

Table 3: Azerbaijan gas prices, $\$ / \mathrm{mcm}$

\begin{tabular}{|c|c|c|c|c|}
\hline & 2013 & 2014 & 2015 & 2016 \\
\hline $\begin{array}{l}\text { Well-head purchases by SOCAR from Bahar } \\
\text { Energy }\end{array}$ & & & & 139.83 \\
\hline \multicolumn{5}{|l|}{ Regulated prices in the domestic market } \\
\hline Wholesale to distributors & 51.00 & 51.00 & 40.00 & 28.00 \\
\hline Retail to end-users & 120.48 & 120.48 & 95.24 & 66.67 \\
\hline Retail to large industrial end-users & 96.40 & 96.40 & 76.20 & 53.30 \\
\hline \multicolumn{5}{|l|}{ Export prices (reported) } \\
\hline Azerbaijan-Georgia & $\mathrm{n} / \mathrm{a}$ & $\mathrm{n} / \mathrm{a}$ & 180 & 165 \\
\hline Russia-Georgia & $\mathrm{n} / \mathrm{a}$ & $\mathrm{n} / \mathrm{a}$ & 210 & $\mathrm{n} / \mathrm{a}$ \\
\hline Russia-Armenia & $\mathrm{n} / \mathrm{a}$ & $\mathrm{n} / \mathrm{a}$ & 165 & 150 \\
\hline Azerbaijan-Turkey & 349 & $\mathrm{n} / \mathrm{a}$ & 340 & $\mathrm{n} / \mathrm{a}$ \\
\hline Russia-Turkey & 428 & $\mathrm{n} / \mathrm{a}$ & 418 & 180 \\
\hline Exchange rate (AZN per \$1) & 0.83 & 0.83 & 1.05 & 1.50 \\
\hline
\end{tabular}

Sources: Greenfields petroleum investor update, June 2016; Tariff Council (domestic regulated prices); media reports and author's estimates (export prices)

\section{Supply-side factors}

One problem has been the reduction in output from SOCAR's own gas fields in the Caspian Sea including the Shallow Water Guneshli field that contributes about $60 \%$ of the company's own production - caused by natural decline. Table 1 shows that the gas output from these fields has fallen in 2010-15, from 6.4 in 2010 to $5.8 \mathrm{bcm}$ in 2015, notwithstanding slight upward spikes in 2012 and 2014. The problem is likely to be exacerbated in 2016 for two reasons: 1 . A shortage of investment funds to take output-enhancing measures and develop new fields. 2. The consequences of a serious accident on platform no. 10, one of three producing platforms at Shallow Water Guneshli, on 4 December 2015, which resulted in 33 fatalities. The accident was caused by a fire on the rig under stormy conditions; the fatalities were apparently linked to the failure of safety equipment (lifeboats). The rig is under repair at the time of writing, and the resulting loss of gas production is estimated at $0.3-0.4 \mathrm{bcm} /$ year. $^{12}$

\footnotetext{
12 "Na melkovodnoi chasti mestorozhdeniia Giuneshli proizoshel pozhar", Neftegaz.ru, 5 December 2015; "Azeri oil disaster an open wound for survivors", Reuters, 12 January 2016; "Na platforme no. 10 mestorozhdeniia Giuneshli ne bylo vyavleno narushenii", Trend news agency, 25 February 2016.
} 

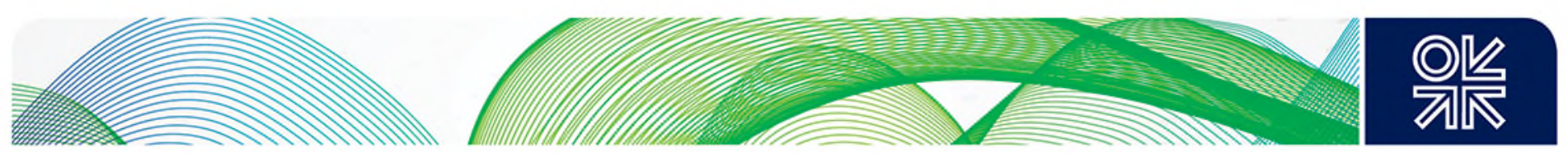

In addition to lower output from SOCAR's own fields, in 2013-14 the volume of associated gas that SOCAR acquired from the Azeri-Chirag-Guneshli (ACG) oil project fell, from 3.0-3.5 bcm/year in previous years to $2.19 \mathrm{bcm}$ in 2013 and $2.76 \mathrm{bcm}$ in 2014 . Although the output of associated gas recovered to $3.2 \mathrm{bcm}$ in 2015 , it is likely to fall further in the next few years as the whole project goes into natural decline. In 2016, industry sources indicate that the associated gas output from ACG is unlikely to be greater than $2.5 \mathrm{bcm}$.

The level of associated gas output from ACG has to be considered in connection with the management of the oil field's decline. ACG is Azerbaijan's largest oil producing field, operated by BP on behalf of a consortium of 11 companies under a 30-year production sharing agreement (PSA) signed with the government of Azerbaijan in 1994, that became known as the "contract of the century". The field went into natural decline in 2010, and most of the associated gas is reinjected into the reservoir in order to maximise the level of oil production during the decline. In 2013 BP reported measures to reduce gas flaring in the Chirag field that brought associated gas utilisation to $97.4 \% .{ }^{13}$ Essentially, at the current point in the field's exploitation, associated gas production can only be increased by sacrificing some current and some future oil production. Managing the volume of associated gas that is brought ashore, rather than being reinjected, has been the subject of something of a political tug-of-war between decision makers with different priorities. The relevant point for the gas balance is that increasing supply from this source can be regarded only as an emergency measure.

\section{Response to supply problems}

SOCAR reduced gas exports to Russia, which had ranged between $0.8 \mathrm{bcm}$ and $1.9 \mathrm{bcm}$ in $2010-13$ $\mathrm{bcm}$, to $0.21 \mathrm{bcm}$ in 2014 (with exports stopping completely during the year) and zero in 2015 . Reports from Georgia suggest that in 2015 Georgian requests for larger volumes of imported gas were turned down due to lack of available volumes. However, terminating exports to Russia and limiting them to Georgia still left Azerbaijan potentially short of gas, and supply side measures were taken as follows in 2015-16:

Proposed imports from Russia. In May 2015, the Azerbaijani methanol producer Azmeco - potentially a major purchaser of gas - signed a contract with Gazprom Export to buy $2 \mathrm{bcm} / y e a r$ of Russian gas for its new plant, which was slated to produce 700,000 tonnes per year of methanol. The plant had been commissioned in 2014 , but in its first year was reportedly forced to interrupt production due to shortages of gas, the main feedstock for methanol production. Deliveries of Russian gas to the plant, which is $220 \mathrm{~km}$ from Azerbaijan's border with Russia, reportedly started on 29 September 2015, but stopped abruptly on 20 October. ${ }^{14}$ Although Azmeco made no public statement on the breakdown of the arrangement, it was widely reported that methanol production was uneconomic when gas was being purchased at import prices of around $\$ 180-190 / \mathrm{mcm}$. SOCAR had been supplying gas at lower prices, around $\$ 130 / \mathrm{mcm}$, but, firstly, SOCAR had insufficient volumes to spare and, secondly, methanol production would probably only become profitable at gas prices below $\$ 100 / \mathrm{mcm} .{ }^{15}$

SOCAR managers have stated that the purchase of Russian gas by large industrial customers - of which Azmeco was a prime example - could resolve the tightness of the gas balance. In February 2016 Elshad Nassirov, a SOCAR vice president, said that SOCAR was ready to facilitate purchases

\footnotetext{
${ }^{13}$ BP Azerbaijan 2013 Year-End Results, on the BP Caspian web site

14 "Gazprom i azerbaidzhanskaia Azmeco dogovorilis' o postavkakh gaza", Vedomosti, 11 Sept 2015; "Azmeco and Gazprom sign contract on gas supply to Azerbaijan", www.contact.az, 14 Sept 2015; "Top official: Azerbaijan stops gas intake from Gazprom", Natural Gas Europe 21 October 2015; "Why did Azmeco need to import Russian gas", Caspian Barrel, 21 October 2015

${ }^{15}$ Other explanations suggested for the breakdown of the arrangement include political (that the USA put pressure on Azerbaijan not to purchase gas from Russia) and related to conflicts between business groups (the president of the Azmeco board, Nizami Piriyev, was arrested in 2015 in connection with a loan from a state-owned bank that the company had failed to pay). But the explanation provided by simple economics remains the most compelling.
} 

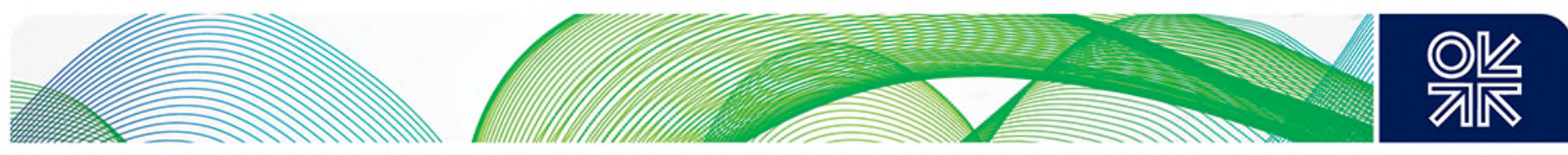

of gas from Gazprom by Azerenergy, its largest and most debt-laden customer. ${ }^{16}$ Azerbaijani industrial consumers can be expected to resist this, in the hope of accessing volumes from SOCAR at Azerbaijan's regulated prices, that are less than one third of Gazprom's reported offer price. In May 2016 it became apparent that SOCAR may seek to close the gap between its commitments to its Azerbaijani customers and its available gas volumes by importing Russian gas itself, as it did up until 2006. Rovnag Abullayev, SOCAR CEO, stated that negotiations have been opened with Gazprom about the purchase of 3-5 bcm/year. ${ }^{17}$

Fuel oil imports. SOCAR has in 2016 started importing fuel oil from Russia and Kazakhstan to supply Azerenergy's thermal power stations, in cases where it has been possible to switch back from burning gas.

Possible future purchases of gas from Turkmenistan. The gas supply squeeze has encouraged Azerbaijani government officials to re-open the question of a trans-Caspian link to supply gas from Turkmenistan. Specifically, they have discussed a scheme under which Azerbaijan would take 3-5 bcm of associated gas from Petronas, which produces oil under a PSA in the Turkmen sector of the Caspian, Petronas currently delivers these volumes to its gas processing plant at Kianly in Turkmenistan, but has been unable to reach agreement with Turkmengaz to sell them either in Turkmenistan or via export. Azerbaijani officials have suggested a scheme under which the gas would be piped back across the Caspian Sea as far as the ACG field, and from there use existing infrastructure to reach Azerbaijan. These proposals have been supported by Natiq Aliyev, Azerbaijan's energy minister, and have received considerable publicity. ${ }^{18}$ But they are unlikely to make progress in the short or medium term for two reasons: 1. Turkmenistan has indicated that it is not interested in sanctioning the arrangement. 2. Whatever name is given to the project, it amounts to a revised version of the proposed Trans Caspian pipeline, and is unlikely to go ahead as long as Russia and Iran remain opposed to it. ${ }^{19}$

Demand-side measures. In addition to the purchase of fuel oil for power stations, mentioned above, SOCAR has reportedly limited sales to industrial and agriculture sector customers in Azerbaijan in order to manage its gas balance. Its managers have also begun publicly to urge the reform of Azerenergy, and policies to address power and heat losses, in addition to other energy efficiency measures.

SOCAR's focus on the range of actions mentioned - directed at importing gas and fuel oil on one hand, and seeking demand-side savings on the other - underlines the fact that, while Azerbaijan is richly endowed with gas resources, particularly offshore, they cannot be developed rapidly enough to address the gas supply squeeze in the short or medium term. The pace of field development, both on SOCAR's own offshore fields and those to be worked under existing or proposed PSAs, will be further slowed because SOCAR's investment funds have been slashed as a result of low oil prices.

The prospects for additional gas production are discussed in section 4, but before that, section 3 addresses the fact that it was widely expected, and not only in Azerbaijan, that some of these resources would be available between 2015 and 2020. These expectations were based on mistaken assumptions.

\footnotetext{
16 “SOCAR gotov okazat' sodeistvie Azerenerdzhi v pokupke gaza u Gazproma”, CBC.az, 1 February 2016

17 "Azerbaidzhan khochet zakupat' u Rossii do 5 milliardov kubov gaza v god", RIA Novosti, 11 May 2016; "SOCAR to purchase gas from Russia”, Azernews, 12 May 2016

18 "Baku, Ashgabat discussing options of Turkmen gas supply via Southern Gas Corridor", Trend.az news agency, 23 May 2016; John Roberts, "Trans Caspian Gas Pipeline interests converging”, Platts Energy Economist, January 2016, pp. 11-14

${ }^{19}$ For a fuller discussion of the Trans Caspian pipeline issue, see Pirani, Central Asian and Caspian Gas, pp. 101-102. There is a more optimistic assessment in: Annette Bohr, Turkmenistan: Power, Politics and Petro-Authoritarianism (London: Chatham House, 2016), pp. 86-88
} 

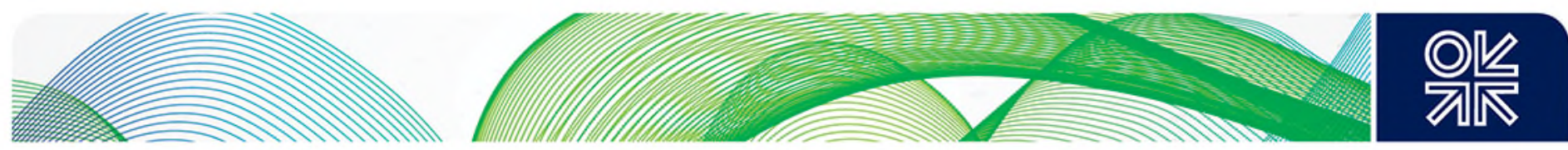

\section{Problematic production estimates}

Azerbaijan has repeatedly been referred to as a major potential source of gas for the European market, and the major source for the Southern Gas Corridor in the 2020s. Given the situation described above in section 2, the validity of such claims should be reassessed. Before doing so, it is important to consider how strong the claims were in the first place, and what assumptions were made to support them. It is instructive to compare estimates made in 2010-13 for future Azeri gas production growth with the situation as it appears now.

For 2020, the IEA, the present author and Wood Mackenzie estimated output of $36 \mathrm{bcm}, 37 \mathrm{bcm}$ and $30 \mathrm{bcm}$ respectively. ${ }^{20}$ Wood Mackenzie's estimate was lower than the others because it assumed that Shah Deniz II would still not have reached plateau production by 2020 . But all three estimates assumed that SOCAR's own production would by 2020 reach $10-11 \mathrm{bcm}$. This now seems extremely unlikely: SOCAR's old fields, which are in natural decline, may by 2020 be producing only $5 \mathrm{bcm} /$ year or less; Umid, which all the estimates expected would be developed faster than it has been, may not contribute more than $1.5 \mathrm{bcm}$ by 2020 . It is therefore very unlikely that SOCAR's own production will be more than $7 \mathrm{bcm}$ in 2020. Had Shah Deniz II reached plateau production by 2020, that would have implied total Azerbaijani output of $33 \mathrm{bcm}$. In fact, Shah Deniz II is expected to produce $10 \mathrm{bcm}$ in 2020 , as it will still be ramping up, implying total Azerbaijani output of $27 \mathrm{bcm}$ in that year.

For 2025, the IEA and Wood Mackenzie have estimated $43 \mathrm{bcm}$ of output; SOCAR's senior managers have estimated $40 \mathrm{bcm}$. The IEA and SOCAR have not produced any disaggregated estimates, and Wood Mackenzie's are available only in the form of a visual graphic. However, it appears that (i) insufficient account has been taken of the fact that Shah Deniz I is expected to be in decline by 2025, (ii) overly optimistic assumptions have been made about the Absheron field and/or other PSA projects, and (iii) output from SOCAR's own fields has again been over-estimated. Let us deal with these elements in turn.

(i) A publicly available forecast from $\mathrm{BP}^{21}$ suggests that by 2025 , Shah Deniz I output will have fallen to $6.7 \mathrm{bcm} / \mathrm{y}$. Shah Deniz II is expected to be at plateau production of about $16.3 \mathrm{bcm} / \mathrm{y}$ at that time, giving a total of $23 \mathrm{bcm} / \mathrm{y}$ from the field.

(ii) In the early 2010s, it was widely expected that development of Azerbaijan's prospective fields would start under PSAs, and estimates assumed that at least one of these would be producing significant volumes of gas by 2025 . These assumptions now appear over-optimistic. The Absheron project is closest to a final investment decision, but the decision has not been taken yet, and given the current low-price environment could be delayed (see below). A contribution of $5 \mathrm{bcm} / \mathrm{y}$ (i.e. projected plateau production) from Absheron by 2025 must now be regarded as a best-case scenario, and not the most likely one. There are other resources that had appeared likely to be developed under PSAs: the most accessible of these is the non-associated (deep) gas at the ACG field - but again, given the slow pace of negotiations, and the fact that their conclusion will now be further postponed due to the low price environment, reaching plateau production by 2025 is not possible. If we make a leap of faith that European hub prices will be at levels which will make Azerbaijani exports viable, and make the best-case assumption on Absheron, then Shah Deniz plus Absheron output could be $28 \mathrm{bcm}$ in 2025 . But a lower figure is more likely.

(iii) Taking that best-case number of $28 \mathrm{bcm}$, is it possible that SOCAR can by 2025 produce $12-15$ $\mathrm{bcm} /$ year of gas from its own assets, to bring total Azerbaijani production to the estimated figures of 40-43 bcm/year? This is a leap too far. Let us assume, optimistically, that output enhancement

\footnotetext{
${ }^{20}$ IEA (2010), "Part D: Outlook for Caspian Energy”, in particular Table 17.10, p. 525; Pirani (2012), p. 108; Shaw (2013), slide 3.

21 "BP in Azerbaijan" presentation (Baku: BP, September 2006), slide 43
} 

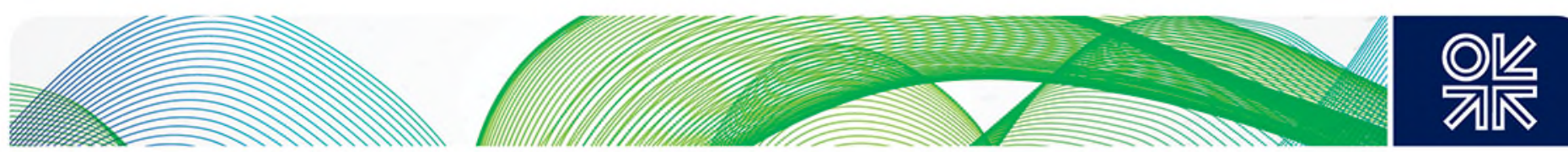

measures keep output from the currently producing fields at $5.5 \mathrm{bcm} /$ year (i.e. $0.3 \mathrm{bcm}$ below my estimate of the 2015 level), and that the Umid field (prior to Babek development) reaches its plateau output level, $1.5 \mathrm{bcm} / \mathrm{year}$. Another $5-8 \mathrm{bcm} / \mathrm{year}$ would still be required. There is no indication as to how that amount of production could be developed in that time scale (see also the next section).

The conclusion is that estimates of Azeri gas output in 2020 and 2025, made in 2010-13, assumed (i) that SOCAR would develop its new fields at an ambitious pace, and (ii) that at least one of the postShah Deniz PSAs would be producing significant volumes by 2025. These assumptions turned out to be wrong. The sharp fall in oil prices in 2014 , and the associated fall in gas prices, means that there are now constraints on investment both by SOCAR and by its potential international partners. Further delay is likely. The situation is re-assessed in the next section.

\section{Outlook for the 2020s and prospects for the Southern Gas Corridor}

Azerbaijan's gas production in the 2020s will comprise: (i) production from Shah Deniz stages I and II; (ii) production from PSAs and prospective PSAs (Absheron, ACG deep, etc), and (iii) production from SOCAR's own fields. The information available about these is:

\section{(i) Shah Deniz I and II}

Estimates of output from the two phases of Shah Deniz, now in the public domain, are shown in Figure 1. The actual output from Shah Deniz I was lower in 2010-12, and higher in 2013-15, than the estimates shown; if it stays at the level of 2013-15 until its decline starts in 2023-24, then the peak of the two phases combined in 2022 may be closer to $26 \mathrm{bcm}$ than the $25 \mathrm{bcm}$ shown in the Figure. As for Shah Deniz II, the Figure reflects assumptions in 2014 by BP, the operator, about its timing, with the field ramping-up to reach about $10 \mathrm{bcm}$ of output in 2020 and to reach plateau output of a little more than $16 \mathrm{bcm} /$ year in 2022.

The Figure also shows that the combined output of the field was expected to start falling from 202324 , due to the decline of the first phase, reaching about $20 \mathrm{bcm}$ in 2030 . (This has a significant implication for export infrastructure planning: by $20241 \mathrm{bcm} / \mathrm{y}$, and by $20306 \mathrm{bcm} / \mathrm{y}$, of spare capacity should be available in the pipelines built for Shah Deniz gas. This is further discussed in section 5.) 

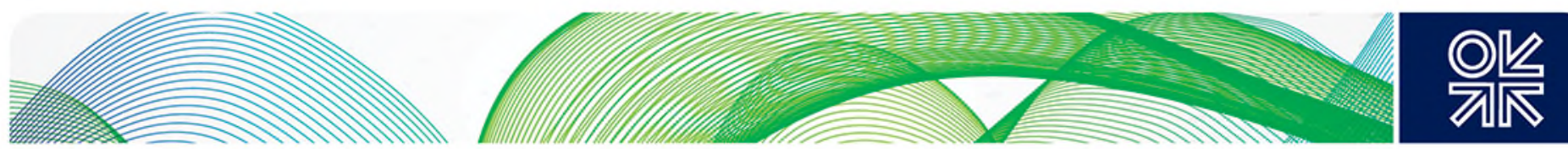

Figure 1: Shah Deniz production estimates

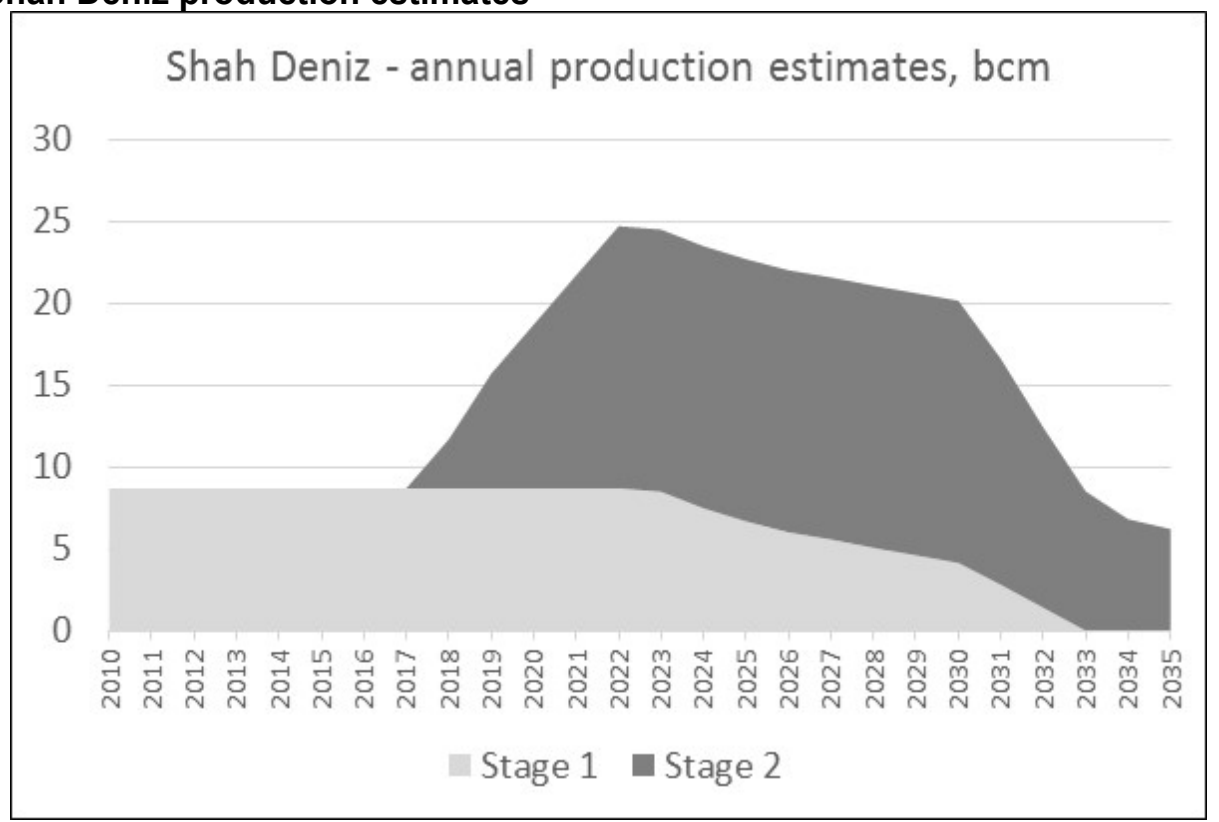

Sources: Stage 1, BP presentation "BP in Azerbaijan. Baku, September 2006", slide 43, "Shah Deniz stage 1 development". Stage 2, Shah Deniz 2 Infrastructure project. Draft Environmental and Socio-Economic Impact Assessment, July 2014, p. 5/6, figure 5.2; author's estimates (stage 1, 2030-33).

\section{(ii) Production from PSAs and prospective PSAs}

Absheron. ${ }^{22}$ The field is covered by a PSA between the government and a consortium of Total (operator, 40\%), SOCAR (40\%) and GDF Suez (20\%). A development programme was drafted in 2015, but has not been agreed; the original intention of taking a final investment decision (FID) in 2016, starting drilling in 2019 and producing first gas in 2021, is therefore in doubt. None of the parties has commented on the negotiations, but the commercial context is clear: while there may be some additional demand for Azerbaijani volumes in Turkey, the most pressing demand is in the domestic market, where sales prices remain low, especially in dollar terms, and are likely to be significantly below the cost of production from new fields (see Table 3 above). Until contracts to sell gas at suitable price levels are in place, it is hard to see the project moving ahead.

ACG non-associated (deep) gas. This large gas resource is quite well known, and the shareholders in the ACG project have been in discussion with the government about the legal framework (e.g. extension of the current PSA, or negotiation of a new PSA) under which it could be developed. My colleague Gulmira Rzayeva estimated that a decision on the legal framework in 2015 would imply a development start date of 2019-20 and first gas in 2027-28;23 there has been no such decision, and in the current low-price environment it is difficult to see one being taken in 2016 or 2017 . The possibility of first gas before 2030 is therefore receding.

Other prospective PSAs, including the Shafag-Asiman project covered by a PSA on exploration and development between the government and BP, are likely to be developed after Absheron and ACG deep gas.

\footnotetext{
${ }^{22}$ For a fuller discussion of all the projects mentioned here, and others, see Rzayeva 2015), pp. 41-59

${ }^{23}$ Rzayeva (2015), p. 49
} 

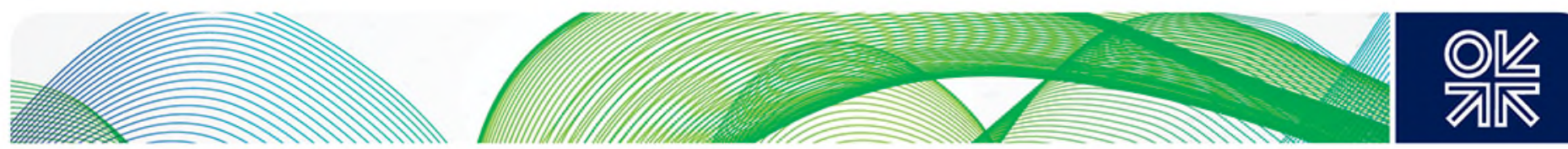

\section{(iii) SOCAR's fields}

There is too little information in the public domain to make an accurate assessment of the production potential of SOCAR's own fields. SOCAR publishes in its annual reports only volumes produced prior to reinjection and flaring, i.e. does not publish commercial volumes produced in line with standard practice. For the gas balance above (table 1), the author has estimated SOCAR's own production as: the national total of commercial gas, minus that produced at the Shah Deniz and ACG fields.

The information available about SOCAR's fields in production and development is summarised in Table 4, together with estimates of their possible ranges of output in 2020 and $2025 .{ }^{24}$ The main uncertainties about the figures in the table are: (i) it is understood that the largest field, Shallow Water Guneshli, is in decline, but there is no information available about the pace of decline or possible output enhancement measures; (ii) there is no indication about how quickly the Umid field may be developed, although industry sources indicate that investment has been reduced for this year, and it is not clear how quickly construction of a second deepwater jacket, needed to complete development, will be completed; (iii) there is no clear timetable for the development of the Babek field; and (iv) apart from the named fields, it is not clear what the level of SOCAR output from other smaller fields is, or might be in future. For all these reasons it should be emphasised that the numbers in the table are nothing more than the most provisional estimates, presented pending the availability of better information.

Table 4: SOCAR's own fields: possible ranges of output (Bcm)

\begin{tabular}{|c|c|c|c|c|}
\hline Field & Comments & 2015 & 2020 & 2025 \\
\hline $\begin{array}{l}\text { Shallow Water } \\
\text { Guneshli }\end{array}$ & $\begin{array}{l}\text { Comprises c. } 60 \% \text { of SOCAR's own } \\
\text { gas production }\end{array}$ & 3.5 & $2-3.5$ & $2-3.5$ \\
\hline Umid & $\begin{array}{l}\text { Drilling work continuing; } 0.357 \mathrm{bcm} \\
\text { produced in 2014; plateau production } \\
1.5 \mathrm{bcm}\end{array}$ & 0.4 & 0.9 & 1.5 \\
\hline Babek & $\begin{array}{l}\text { To be developed after Umid; plateau } \\
\text { production } 3-5 \mathrm{bcm}\end{array}$ & 0 & 0 & $0-3.0$ \\
\hline Gum-Deniz/Bahar & $\begin{array}{l}\text { Being developed in a joint venture with } \\
\text { Greenfields Petroleum }\end{array}$ & 0.2 & 0.57 & 0.17 \\
\hline Bulla Deniz & $\begin{array}{l}0.34 \mathrm{bcm} \text { produced in } 2013 \text {; plateau } \\
\text { production } 1.4 \mathrm{bcm}\end{array}$ & 0.4 & $0.4-1.4$ & $0.4-1.4$ \\
\hline Other & Residual figure estimated by author & 1.3 & 1.3 & 1.3 \\
\hline Total & & 5.8 & $5.17-7.67$ & $5.37-10.87$ \\
\hline
\end{tabular}

\section{Summary}

The possible ranges of output discussed above are summarised in Table 5 . It shows that the possible range of output in 2020 is lower than the estimates discussed in section 3 , and that the previous estimates for 2025 output would only be reached if both Absheron attains its plateau output, which is unlikely, and the SOCAR fields attain the upper limit of this author's possible range of output, which is unlikely.

24 There are detailed descriptions of SOCAR's fields in Rzayeva (2015), pp. 32-37 and 46-48 

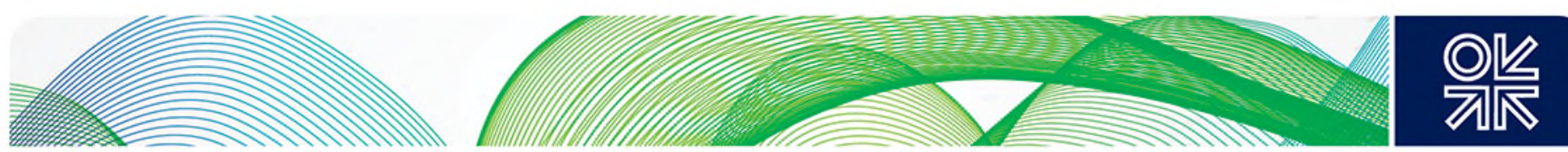

Table 5: Summary of possible ranges of output $(\mathrm{Bcm})$

\begin{tabular}{|c|c|c|c|}
\hline & 2015 & 2020 & 2025 \\
\hline Shah Deniz I & 9.9 & 10 & 7 \\
\hline Shah Deniz II & 0 & 10 & 16.3 \\
\hline ACG associated gas & 3.2 & $2-3$ & $2-3$ \\
\hline Absheron & 0 & 0 & $0-5$ \\
\hline SOCAR fields & 5.8 & $5.2-7.7$ & $5.4-10.9$ \\
\hline Total & 18.9 & $27.2-30.7$ & $30.7-42.2$ \\
\hline
\end{tabular}

The implications for Azerbaijan's gas balance are as follows. Of the gas produced in 2020, up to 18.8 bcm $(6.6 \mathrm{bcm}$ to Turkey under its Shah Deniz I contract, $10 \mathrm{bcm}$ to Shah Deniz II counterparties and $2.2 \mathrm{bcm}$ to Georgia) could be under contract for export, leaving 8.4-11.9 bcm for domestic consumption. SOCAR forecasts $11.8 \mathrm{bcm}$ of domestic consumption in $2020,{ }^{25}$ and would presumably have to make up any shortfall (up to $3.4 \mathrm{bcm}$ ) with Russian imports.

The situation changes in 2021, when the Shah Deniz I contract with Turkey comes to an end. From that point, contracted sales from Shah Deniz II are $6 \mathrm{bcm}$ to Turkey and $10 \mathrm{bcm}$ to Europe; it may reasonably be assumed that there will be demand in Georgia for 2.2-2.5 bcm of Azerbaijani gas, making an export requirement of $18.2-18.5 \mathrm{bcm}$. So in 2025, if no additional gas is being sold to Turkey, after fulfilling that requirement Azerbaijan may have 12.2-24 bcm of gas to meet domestic commitments, which are forecast by SOCAR at $13.1 \mathrm{bcm}$. On the other hand if output is at the lower level suggested by table $5,12.2 \mathrm{bcm}$ of domestic demand can be covered, and a little under $1 \mathrm{bcm}$ of Russian imports would be required. Only if output reaches the higher level suggested by table 5, which seems unlikely, could domestic demand be covered and a significant volume of gas $-10.9 \mathrm{bcm}$ - be available for additional exports. (There will of course be pricing issues, e.g. the Shah Deniz consortium, that has so far been receiving export prices for its gas, will presumably try to maintain its access to those.)

To summarise: only if Azerbaijan successfully regains momentum in field development, and by 2025 gets close to the higher level of output suggested in table 5, will it have any significant volume of gas - additional to Shah Deniz 2 - to export and if it does, the most obvious destination for this gas would be Turkey.

\section{Implications for the Southern Corridor and conclusions}

The above analysis makes clear that, apart from the volumes committed to Turkey and Europe from Shah Deniz II, and 2.2-2.5 bcm of gas for Georgia, by 2025 Azerbaijan is very unlikely to have 10 $\mathrm{bcm} /$ year or more available for export. It is indeed more likely that, if field development proceeds more slowly, at the lower end of the ranges of output summarised in table 5, Azerbaijan would have no

\footnotetext{
25 This consumption forecast does not include projects that would increase gas demand substantially, and that are now understood to be on hold, such as the methanol plant discussed above, or the much larger ( $\$ 12$ bn) OilGas Processing and Petrochemical Complex (OGPC) planned for construction at Sangachal, which would require 12 bcm/year of gas feedstock. (For details see John Roberts, "Trans Caspian Gas Pipeline interests converging", Platts Energy Economist, January 2016, pp. 11-14.)
} 

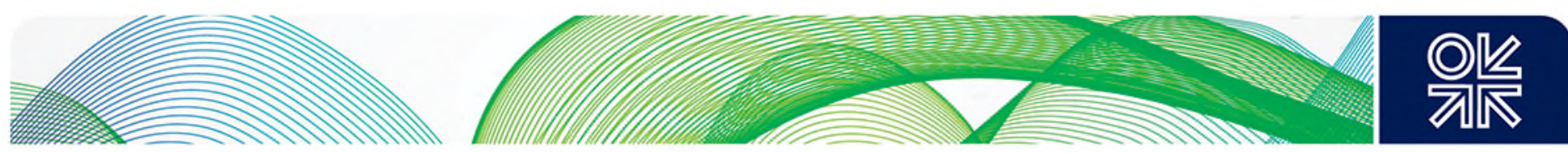

additional gas to export, and will still require small volumes of Russian imports for its own gas balance. If Azerbaijani output is in the middle of the range presented in table 5, e.g. 35-36 bcm/year, then there would be 3.7-4.7 bcm/year spare to export. Assertions e.g. that "gas volumes [to be transported via the Southern Corridor] are slated to increase to $35 \mathrm{bcm}$ as other gas fields in Azerbaijan come online after 2020" are misleading. 26

While the volumes of non-Shah Deniz gas available will be very limited, small volumes from Shah Deniz itself could be available for the market, for two reasons:

1. Volumes sold under contract by the Shah Deniz II consortium could be less than the contract quantities. This is possible if the current market conditions in Europe, of potential oversupply and low gas prices, continue into the 2020 s - a scenario made more likely by the prospect of price competition in Europe between Russian imports and LNG. ${ }^{27}$ If, for example, only $85 \%$ of the contracted volumes are sold, this would free up a further $2.4 \mathrm{bcm}$ of gas - although, equally, if those market conditions and low prices persist, Azerbaijani gas will struggle to compete, as discussed below. (It should be borne in mind that most of the Shah Deniz II volumes, with the exception of those committed to Bulgargaz of Bulgaria and Depa of Greece, have been contracted to traders or aggregators whose sales policies will be dictated by market conditions.)

2. As stated above, volumes from Shah Deniz I may be available after the expiry of the current sales contract with Turkey in 2021. Negotiations are continuing between Azerbaijan and Turkey about renewing this contract, and it seems reasonable to assume that some of these volumes will be sold in Turkey. On the other hand, additional sales to Europe seem unlikely. Not only will Azerbaijan at best have only limited volumes to spare, but the additional cost of transporting them to Europe means they will be less competitive there than in Turkey.

In addition to volume constraints, there are price constraints on the sale of Azerbaijani gas in Europe.

Some rough figures on production and transport costs for Shah Deniz II gas, based on estimates by industry sources, are as follows:

Cost of delivering gas to Italy $=\$ 273-293 / \mathrm{mcm}=\$ 7.54-8.09 / \mathrm{MMbtu}=$ (at current values) $€ 22.8-$ 24.5/MWh comprising (cost of production at Shah Deniz, $\$ 50-60 / \mathrm{mcm}$; transport through the South Caucasus pipeline (to the Georgian/Turkish border), \$50; transport through TANAP (to the Trakya (Thrace) delivery point on the Turkish/Greek border), $\$ 103 / \mathrm{mcm}$; transport through the TAP pipeline to Italy, $\$ 70-80 / \mathrm{mcm})$.

Cost of delivering gas to Turkey $=\$ 179-189 / \mathrm{mcm}=\$ 4.94-5.22 / \mathrm{MMbtu}=$ (at current values) $€ 15.0-$ 15.8/MWh comprising (production at Shah Deniz, $\$ 50-60 / \mathrm{mcm}$; transport through SCP, $\$ 50 / \mathrm{mcm}$; transport through TANAP by Botas to the Eskisheher delivery point, $\$ 79 / \mathrm{mcm}){ }^{28}$

Caveats are (i) that the production cost figure is an estimate, and takes no account of some complex variables, in particular the contribution of sales of liquids from Shah Deniz II, and (ii) that lower capital costs on TANAP, announced recently, could make possible a lower tariff. But neither of these factors change the overall picture.

Azerbaijani gas is not competitive in Europe at current market prices, and indeed gas produced from deep-sea deposits and transported over long distances will always struggle to compete in a low-price environment. On the other hand Azerbaijani gas can be competitive in Turkey, and potentially competitive in the small markets of south-eastern Europe, e.g. the Balkan countries. Indeed it may

\footnotetext{
${ }^{26}$ Assenova and Shiriyev(2015), p. xv.

${ }^{27}$ See, for example: Henderson and Mitrova (2015)

${ }^{28}$ The transport tariffs for TANAP have been made public in the inter-governmental agreement between Azerbaijan and Turkey (Inter-governmental agreement between Turkey and Azerbaijan, clause 2.2.4). The other estimates here have been shared with the author by industry sources.
} 

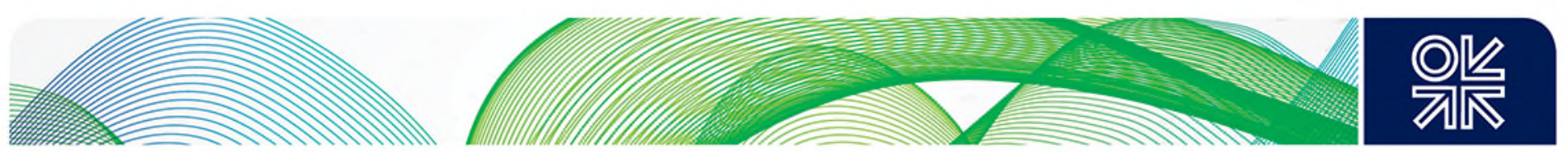

well be that the significant contribution of Azerbaijani gas exports in the 2020s will be first in Turkey and second in south-eastern Europe, rather than in the larger European markets where the volumes likely to be available will not make a major impact.

A final point to be made about the southern corridor concerns infrastructure. As noted above (in section 4(i), with respect to Figure 1), the projected decline of Shah Deniz I means that by 20241 bcm, and by $20306 \mathrm{bcm}$, of spare capacity should be available in the pipelines built for Shah Deniz gas. From 2030, the much more rapid decline of Shah Deniz II is expected, and by 2035 a further 13 $\mathrm{bcm}$ of spare capacity is likely to be available in the existing pipeline system. Given the volumes of Azerbaijani gas that are likely to be available for export, and the timing, it seems possible that much, if not all, of them may be matched with existing infrastructure. At most, some relatively small-scale expansion of the infrastructure might be required, e.g. if further long-term sales contracts were agreed between Azerbaijan and Turkey.

Certainly no large-scale expansion of the infrastructure will be required in the foreseeable future; statements such as that by Azerbaijan's energy minister, Natiq Aliev, envisaging expansion of the South Caucasus pipeline to a capacity of $50 \mathrm{bcm} / \mathrm{year},{ }^{29}$ are simply misleading. Similarly, an expansion of TANAP to $31 \mathrm{bcm} /$ year capacity, which has been the subject of public discussion, ${ }^{30}$ would imply higher tariffs, unless additional volumes were forthcoming: what would its economics look like then?

\section{Conclusions}

First, estimates made in 2010-12 of Azerbaijani gas production in the 2020s assumed that SOCAR's own new fields would be developed, and PSA negotiations concluded, more rapidly than has happened. Output has therefore risen more slowly than was widely expected. On the demand side, Azerbaijani and Georgian demand have risen robustly, and Turkish offtake under the Shah Deniz I contract has in 2014-15 risen to contract quantity levels. These are the main causes of the supply squeeze, to which Azerbaijan has reacted by (i) importing fuel oil, and considering imports of Russian gas, and (ii) with proposals for demand-side measures.

Second, substantial volumes of new production - excluding Shah Deniz II gas which is already committed under contract to Turkish and European buyers - will come first of all from the Absheron project and potentially from SOCAR's own resources. But the low price environment, and the associated delays in investment, means that Absheron is now very unlikely to start producing in 2021 as planned. As for SOCAR's own fields, there is insufficient information to make any accurate judgment on how output from them might evolve.

Third, the Azerbaijani gas supply squeeze will therefore last until at least 2021. At that point, with the expiry of the Shah Deniz I contract with Turkey, some gas from Shah Deniz I as it declines could become available - although presumably the consortium that produces it will hope to sell it at export prices rather than on the domestic market. If new production is brought on in the early 2020s, some of it could be available for export.

Fourth, the fact that the volumes involved will be small (certainly no more than $10 \mathrm{bcm} / \mathrm{year}$ by 2025 , and probably far less) and that, given the transport costs, it will struggle to compete with other imports to Europe, mean that it is unlikely that substantial new volumes will reach Europe's larger markets.

\footnotetext{
${ }^{29}$ Speech by Natiq Aliev at the Caspian Oil and Gas Conference, Baku, 1 June 2016.

${ }^{30}$ The TANAP holding company states that the pipeline will be expanded from its first-stage capacity of 16 bcm (due to be commissioned in 2018) to 24 bcm and then 31 bcm. See for example press release of 13 March 2015, "Major shareholder in the project of the century", http://www.tanap.com/media/press-releases/major-shareholder-in-the-project-of-the-century/
} 

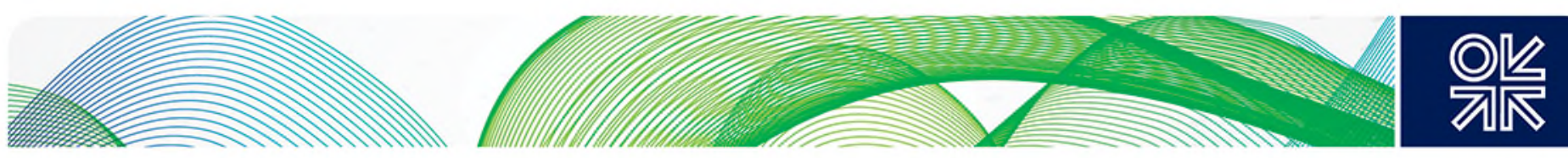

Azerbaijani gas could make a significant difference to the small markets in south-eastern Europe, particularly in cases where diversifying away from Russian supply is a policy priority. Apart from this, it would be commercially more logical for Azerbaijani gas to be sold in Turkey than in Europe.

Fifth, substantial volumes of Azerbaijani gas will not be available for Europe until the commodity cycle has turned, sizeable investment funds are available, more PSAs are signed and fields developed, and SOCAR's own production increases. It is unlikely that all this will happen by 2030 . This in turn means that, for the Southern Gas Corridor to provide substantial supply diversification for Europe during the 2020s, significant volumes would have to be acquired from Iraq, Iran, Turkmenistan (or other Central Asian countries) or East Mediterranean sources. 

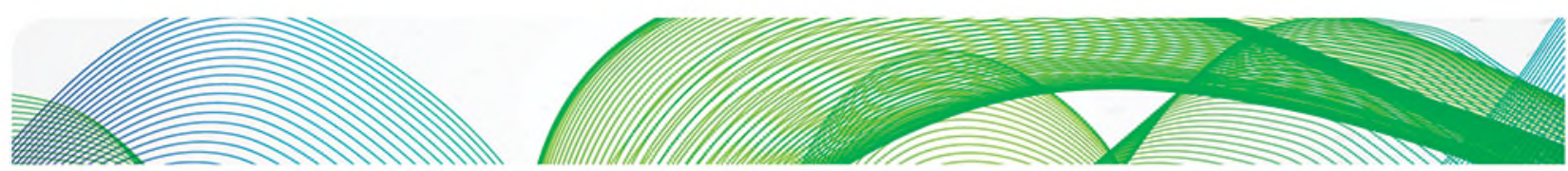
$\mathrm{OW}$

\section{Bibliography}

Assenova and Shiriyev, (2015), Azerbaijan and the New Energy Geopolitics of Southeastern Europe (Washington: The Jamestown Foundation, 2015).

http://www.jamestown.org/single/?tx_ttnews\%5Bswords\%5D=8fd5893941d69d0be3f378576261ae3e \&tx_ttnews $\% 5$ Bany_of_the_words $\% 5 \bar{D}=$ assenova\&tx_ttnews $\% 5 \mathrm{Btt}$ news $\% 5 \mathrm{D}=44122 \& \mathrm{tx}$ _ttnews $\% 5$

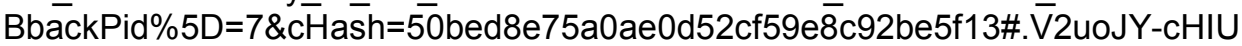

Bohr, Annette (2016), Turkmenistan: Power, Politics and Petro-Authoritarianism (London: Chatham House, 2016), https://www.chathamhouse.org/publication/turkmenistan-power-politics-and-petroauthoritarianism

Bowden, Julian (2011), "Azerbaijan: from gas importer to exporter" in S. Pirani (ed.), Russian and CIS Gas Markets and Their Impact on Europe; https://www.oxfordenergy.org/shop/russian-and-cis-gasmarkets-and-their-impact-on-europe/

BP Azerbaijan 2013 Year-End Results, on the BP Caspian web site, http://www.bp.com/en_az/caspian.html

Henderson, James and Mitrova, Tatiana, (2015), The Political and Commercial Dynamics of Russia's Gas Export Strategy (OIES, September 2015), https://www.oxfordenergy.org/wpcms/wpcontent/uploads/2015/09/NG-102.pdf

IEA (2010), World Energy Outlook 2010, "Part D: Outlook for Caspian Energy", http://www.worldenergyoutlook.org/

IMF (2013), Republic of Azerbaijan: Selected Issues (country report 13/165) (June 2013), http://www.imf.org/external/pubs/ft/scr/2013/cr13165.pdf

Pirani,S (2012), Central Asian and Caspian Gas Production and the Constraints on Export (OIES Working Paper, 2012), https://www.oxfordenergy.org/publications/central-asian-and-caspian-gasproduction-and-the-constraints-on-export/

Rzayeva, Gulmira (2015), The Outlook for Azerbaijani Gas Supplies to Europe (OIES Working Paper, 2015), https://www.oxfordenergy.org/wpcms/wp-content/uploads/2015/06/NG-97.pdf

Rzayeva, Gulmira (2014), Natural Gas in the Turkish Domestic Energy Market - Policies and Challenges (OIES Working Paper, 2014), https://www.oxfordenergy.org/publications/natural-gas-inthe-turkish-domestic-energy-market-policies-and-challenges/

Shaw, Matthew (2013) Shaw (Wood Mackenzie), "Azerbaijan's Gas Supply: Potential and Challenges", presentation at the Caspian Oil and Gas Conference, Baku, June 2013 http://www.woodmac.com/reports/gas-markets-azerbaijans-gas-supply-potential-and-challenges17701737. 